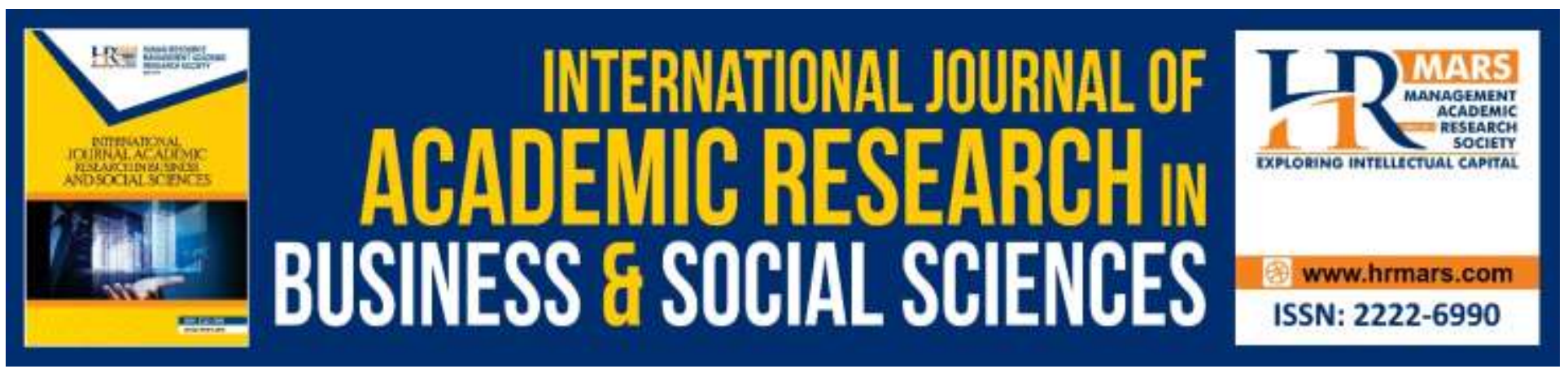

\title{
The Importance of Game Development Framework (GDF): Proposing an Islamic Game Development Framework with Sustainability Features
}

\author{
Nadiah Bt. Ramlan, Norasikin Bt. Fabil
}

To Link this Article: http://dx.doi.org/10.6007/IJARBSS/v10-i3/7078

DOI:10.6007/IJARBSS/v10-i3/7078

Received: 02 February 2020, Revised: 22 February 2020, Accepted: 12 March 2020

Published Online: 28 March 2020

In-Text Citation: (Ramlan \& Fabil, 2020)

To Cite this Article: Ramlan, N. B., \& Fabil, N. B. (2020). The Importance of Game Development Framework (GDF): Proposing an Islamic Game Development Framework with Sustainability Features. International Journal of Academic Research in Business and Social Sciences, 10(3), 633-644.

Copyright: (C) 2020 The Author(s)

Published by Human Resource Management Academic Research Society (www.hrmars.com)

This article is published under the Creative Commons Attribution (CC BY 4.0) license. Anyone may reproduce, distribute, translate and create derivative works of this article (for both commercial and non-commercial purposes), subject to full attribution to the original publication and authors. The full terms of this license may be seen at: http://creativecommons.org/licences/by/4.0/legalcode

Vol. 10, No. 3, 2020, Pg. 633 - 644

Full Terms \& Conditions of access and use can be found at http://hrmars.com/index.php/pages/detail/publication-ethics 


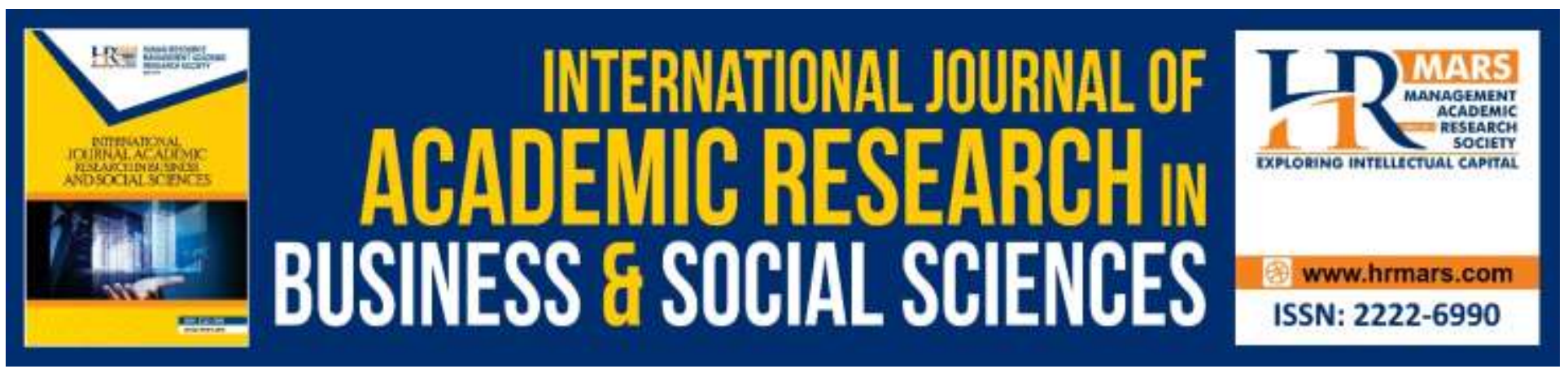

\title{
The Importance of Game Development Framework (GDF): Proposing an Islamic Game Development Framework with Sustainability Features
}

\author{
Nadiah Bt. Ramlan, Norasikin Bt. Fabil \\ Faculty of Science and Technology, Islamic Sciences University of Malaysia (USIM), Nilai, \\ Malaysia
}

\begin{abstract}
This paper highlights the game development framework (GDF) that applies the theory of learning and embodied the theory in games. In order to examine whether the appropriate game development framework (GDF) will have an impact on the motivation and performance of students in the subject, the researcher considers multiple factors related to the game development framework as well as technical factors. A search by Google Scholar search engine was used for the relevant journal article, books, and conference proceedings related to the subject from the years 2010-2016. Searched literature was filtered and selected based on the definition and categorization of games by scholars (including subject discipline and platform/delivery) and the advantages of games in teaching and learning. This paper suggests that the game development framework (GDF) should be approached as a systematic learning system based on the principle of learning theory, learning goal, learning outcome, instructional design, game features, plus with sustainability features. Thus, it may influence the impact of the game on the teaching and learning process.
\end{abstract}

Keywords: Game Development Framework, Islamic Education, Instructional Design.

\section{Introduction}

Information, Communication, and Technology (ICT) are becoming very important nowadays. In order to support our daily routine activities, we can employ different kinds of technologies, particularly when it comes to the completion of our work and tasks. One example of the current technology is computer games. Teachers use games as education tools to provide opportunities to learn more. Furthermore, students can get a meaningful experience and the learning procedure becomes easier and more enjoyable.

Most of the earlier computer games study focused only on the negative impact of playing games instead of the positive impact (Connolly, Boyle, Macarthur, \& Hainey, 2012). Ogletree \& Drake (2007) reported that the play of digital entertainment had a negative effect in regulating the amount of 
time used to play games. Despite the adverse effects of computer games, the positive effect of playing games also appeared. Research shows that games integrating into a children's classroom can help with academic performance, motivation, and dynamics.

In the meantime, several studies have been discussed on the impact of the use of games in teaching subjects such as mathematics, science, geography, and language. However, the study that focuses on the impact of the use of games in the teaching of Islamic subjects is still limited. According to Rosas, Nussbaum, Cumsille, et al., (2003), games are used in schools for many years in an interesting and motivational way for children to learn math, language, geography, science, and other subjects. In one form or the other, technology has always been a part of the teaching and learning environment. It belongs to the professional toolbox of the teacher. This means that teachers use some resources to facilitate student learning. Moreover, multimedia can create high-quality learning environments. The learning process becomes more active, stimulating, entertaining, effective, and fun with multimedia. The key elements of multiple medias such as audio, video graphics, text, and animation, the user's ability to control over the delivery of information, and the interactivity it provides can be used to improve the learning process by creating integrated learning environments (Jusoh \& Jusoff, 2009; Cairncross \& Mannion, 2010).

This paper therefore seeks to develop the Islamic games development framework (IGDF), a good play that meets the objective of education. In order to take into account is the principles of learning theory, learning goal, learning outcome, instructional design, game characteristics and sustainability features, which may influence the impact of the learning process. Games appear to be an effective teaching tool as they have several multimedia elements to solve certain problems, as they could transform traditional classrooms into a unlimited imaginary world (Norhayati \& Siew, 2004).

\section{Literature Review}

\section{A Related Study on Games}

\section{Games Development Process- Selection of appropriate game development framework (GDF).}

Selecting an appropriate game development framework (GDF) is very important in the development of games. It is intended to ensure that the goal of the games will have a positive impact on the development of the learners. Derryberry (2010) indicated that games have been designed to improve certain specific aspects of learning. The main component of a game development framework is playing an important contributor to human development, maturation, and learning.

In addition, the criteria for selecting an appropriate GDF are considered to be an important procedure during the preparation work for teaching. This process can be described in the following steps: 1) finding different GDF candidates, 2) analyzing the characteristics of each GDF, 3) setting criteria for filtering GDF candidates, and choosing one or more GDFs that are best suited to the course content (Wu \& Wang, 2012)

One example is Yang and Chang (2013), which provided students with digital games based on the content of their biological courses to enable them not only to retain their content but also to improve critical thinking skills. The common element of the three approaches to GBL is the need for a video game. 
INTERNATIONAL JOURNAL OF ACADEMIC RESEARCH IN BUSINESS AND SOCIAL SCIENCES

Vol. 10, No. 3, March, 2020, E-ISSN: 2222-6990 @ 2020 HRMARS

\section{Theories embodied in games: Learning theory and instructional design theory Learning theory}

Gagné's Nine events of instruction theory inform that there are several different types or levels of learning, implying that each type also requires a different approach to instruction. Good games are supposed to do this. Game designers use multiple ways of supporting and challenging players. According to Gagné, "an instructional plan can generate both appropriate environmental stimuli and instructional interactions, which can lead to a change in the cognitive structures and operations of the learner".

In addition, each of Gagné's five categories of learning is well supported in most good games, as verbal and textual information is provided. Gagné's Nine Events Applied to Games: First, gaining attention (reception). This is referred to as "attraction mode" in games; this is what you see when a game appears to be playing on its own - it shows elements of the game play and is intended to attract players to play. This aspect is also addressed by introducing the game when you start to play; often with prepared video clips that are typically of high-quality production.

Second, informing learners of the objective (expectancy). This is typically part of the backstory and a description of the victory condition. Third, stimulating recall of prior learning (retrieval). The back-story associated with introducing a game provides the reference frame sequels and new levels sometimes refer to things learned in previous levels/versions. Reminder stimulation can be both explicit and implicit.

Fourth, presenting the stimulus (selective perception). This aspect is controlled in the game and is intended to provide both encouragement and challenge. Fifth, providing semantic encoding for learning guidance. Sixth, eliciting performance (responding). This is, of course, an essential component of interactivity, without this, there really is no game. Seventh, providing feedback (reinforcement). Feedback is provided in number of ways, including scores; displays; queries; and verbal feedback. Eight, assessing performance (retrieval) which means, feedback and assessment are typically coupled to games. Finally, enhance retention and transfer (generalization).

\section{Instructional Design Theory}

Next, the ASSURE model is an instructional system or guideline that teachers can use to develop lesson plans which integrate the use of technology and media (Smaldino, Lowther \& Russell, 2008). It focuses on the learner and the overall outcome of the achievement of learning objectives. The ASSURE model is an enriched evolution of the ADDIE general model. While the ASSURE model has six steps that do not exactly match the five of ADDIE, ASSURE also presents design phases and shares the two main features with it: the initial focus on analysis and the cyclic structure.

The ASSURE model is preferred by teachers as it is intended for a few hours of instruction and for each student. It does not necessitate highly complexity of the delivered media, deep ID knowledge and highly revised design (Gustafson \& Branch, 2002). The main difference between an inexperienced teacher and an expert teacher is that it is easy for an expert teacher to decide on content, appropriate teaching strategies and delivery medium. The ASSURE model provides new teachers, which are not experienced, with a general roadmap to help them think more like expert teacher. 
INTERNATIONAL JOURNAL OF ACADEMIC RESEARCH IN BUSINESS AND SOCIAL SCIENCES

Vol. 10, No. 3, March, 2020, E-ISSN: 2222-6990 @ 2020 HRMARS

The ASSURE Model consists of six steps, each represented by a letter in the acronym title, each of which describes a set of tasks that are central to the informed selection and use of educational technology. The acronym ASSURE stands for these important components.

Another well-known instruction design model is the MRK (Morris, Ross, and Kemp). The Morris Ross and Kemp model "emphasizes the adoption of continuous implementation and evaluation through the instructional design process" (Hanley, 2009). According to Morrison, Ross and Kemp (2004), there are nine key elements for instructional design. Compared to the ADDIE and ASSURE model, the MRK model focuses on design and plan of the entire curriculum.

\section{Technical Factors: Goals of the Games and Sustainability Features The Goal of Games}

The stated goal of the game is the important part of any type of games being developed. The goal of the game for college students, for example, is to develop a solid understanding of building concepts and practices for sustainability. Based on Bloom's taxonomy of learning objectives, the use of games in education is a promising tool for motivating and engaging students in their learning process (Cruz, 2003).

There is a common understanding in the research evidence-base that games should be goal directed, competitive and designed within a framework of rules, choices and feedback to enable teachers and students to monitor progress towards the goal. Gaming attributes such as a score mechanism or a resolving puzzle should communicate goals, which in turn adds a competitive factor and a player's decision informed by a specific choice. These goals are achieved by the player using specific choices. Choices in games relate to the number of decisions that a player has before and during a game (Hannafin and Peck, 1988).

Moreover, the game goals are the key concept of game design that must be revised on all factor designs. The designer should think about what type of experience players can have to offer, which might include a magical medieval world, different races players can choose from, or cooperation versus mode. It is a game that satisfies the pleasure of playing and engagement, then it attracts more people to take part (Shi \& Shih, 2013).

Besides all good video games, one crucial learning principle should also be incorporated, which is a proper level of difficulty. If the learning tasks of individuals are too easy, they will not make enough errors to improve themselves. Conversely, if they find a learning task too difficult, the error signals may be uninformative and will therefore learn nothing again.

Game designers should therefore set specific goals, which can guide players to explore game content and the most important things to satisfy their players. Educational psychologists have long believed that the most effective learning paradigms keep individuals right at the edge of their ability in what they call the "zone of proximal development" (Vygotsky 1978). The game designer should carefully determine the initial difficulty level of the game in this dynamic process and increase it to improve learning by the individual player. 


\section{Sustainability Features}

This section describes the sustainability features of good game design. First, games act as a tutor. It means that learning how to play is accomplished in the game itself. In effect often using sophisticated "just-in-time" approaches to provide assistance.

Second, it is necessary to consider the objective components of the game, such as the types of players, the game interface and physically and logically informing players of the current state of the game (e.g. tokens showing the player that is under control or physically describing gamespace as chess squares).

Third, state the appropriate instructions. The peculiar feature of this model is that it focuses on "planning and conducting instructions that incorporate media" (Heinich, Molenda \& Russel, 1993). Its main point of view is how to integrate media (any type of media) into instruction in a method that can produce the desired learning results.

Forth, make the game as fun instructional development that can be incorporated into other instructional activities to make it more enjoyable for the learner (Garris, Ahlers, \& Driskell, 2002). For example, Parker and Lepper (1992) found that learners preferred educational programmed that included fantasy elements. They also found that, compared to activities without fantasy elements, learners showed greater learning and retention under fantasy conditions.

Fifth, the games must be self-contained and stimulate. This means that players do not use manuals, and players do not normally have an "facilitator" to help them learn how to play. A game that is not stimulating enough for the target audience will fail to keep their attention, receive a poor rating, and eventually fail economically.

\section{Advantages of Using Games in the Teaching and Learning Process}

Previous research suggests that the use of game or game elements can even enhance the classroom atmosphere (Yang, 2012). It has been mentioned that video games can be appealing and motivating to new generations of students who have grown up in the age of video games (Glover, 2013). The immediate and frequent feedback video games offer is another advantage of using video games for educational purposes (Kapp, 2012).

Furthermore, behavioral research shows that games can provide a variety of basic psychological needs. These include autonomy (the belief that one has control over his or her own actions and decisions), competence (the belief that one has the level of skill needed to achieve goals), and relatedness (the feeling that one is socially connected to other human beings. (Przybylski, Rigby and Ryan 2010).

Hainley and Henderson (2006) contests that games have variable outcomes permeated, for example, in the form of a game journal (Dunwell et al., 2015), at the beginning, during or at the end of each level. Combining these principles on the effects of game outcomes on the player, Bloom's taxonomy sought to align closely with game features and models allowing games to be fun, including a learning purpose as a means of better understanding how knowledge is gained.

In conclusion, games can facilitate and inspire students ' learning and creativity. Teachers' roles are necessary to use their knowledge and technology to facilitate experiences which promote student learning, creativity and innovation, both in face-to-face and virtual environments. In addition, the use of games can give students the opportunity to explore real problems and to solve 
INTERNATIONAL JOURNAL OF ACADEMIC RESEARCH IN BUSINESS AND SOCIAL SCIENCES

Vol. 10, No. 3, March, 2020, E-ISSN: 2222-6990 C 2020 HRMARS

genuine problems. In addition, student reflection should be promoted using collaborative tools to reveal and clarify the conceptual understanding and thinking, planning, and creative of students.

\section{The Challenge of Using Games in Teaching and Learning}

At any time during the game, students apply the three sustainability concepts Reduce, Reuse and Recycle; after a decision has been taken, the game provides feedback on the environmental and society impact of that choice. For example, when a player changes water fixtures to low flow (application of the principle of reduce) the game displays an animation that shows how this reduction can be translated into the provision of drinking water for additional people. The game becomes more challenging as the player moves to higher levels (Dib \& Adamo-Villani, 2014).

Video games use a number of methods to ensure that players remain at a challenging level but have tasks they can accomplished. For example, almost all games provide a number of usercontrolled difficulty settings (such as "casual" or "expert"), some of which can only be attempted by players after they demonstrate a low difficulty level proficiency (Eichenbaum , Bavelier, and Green, 2014).

In addition, a game is a series of interesting choices (Juul, 2005). An interesting choice is mentally challenging, strategic rather than skill oriented. In addition to categorizing learning activities that may be enacted in games, it is important to think about learning outcomes mapped out to such activities.

\section{Method}

Relevant journal articles, books, and conference proceedings related to the subject were searched from 2010 to 2016 using the Google Scholar search engine. For the first time, 50 articles related to technology and games have been identified.

Subsequently, the literature searched was filtered and selected on the basis of three categories: definition and categorization of games by scholars (including subject discipline and platform/delivery), use of games in teaching and learning, and use of games. Finally, only relevant literature was considered and subsequently categorized with its study scope, field of study, research participants, and technologies used. 
INTERNATIONAL JOURNAL OF ACADEMIC RESEARCH IN BUSINESS AND SOCIAL SCIENCES

Vol. 10, No. 3, March, 2020, E-ISSN: 2222-6990 C 2020 HRMARS

Findings and Discussion

A Proposed framework of Islamic games development framework (IGDF)

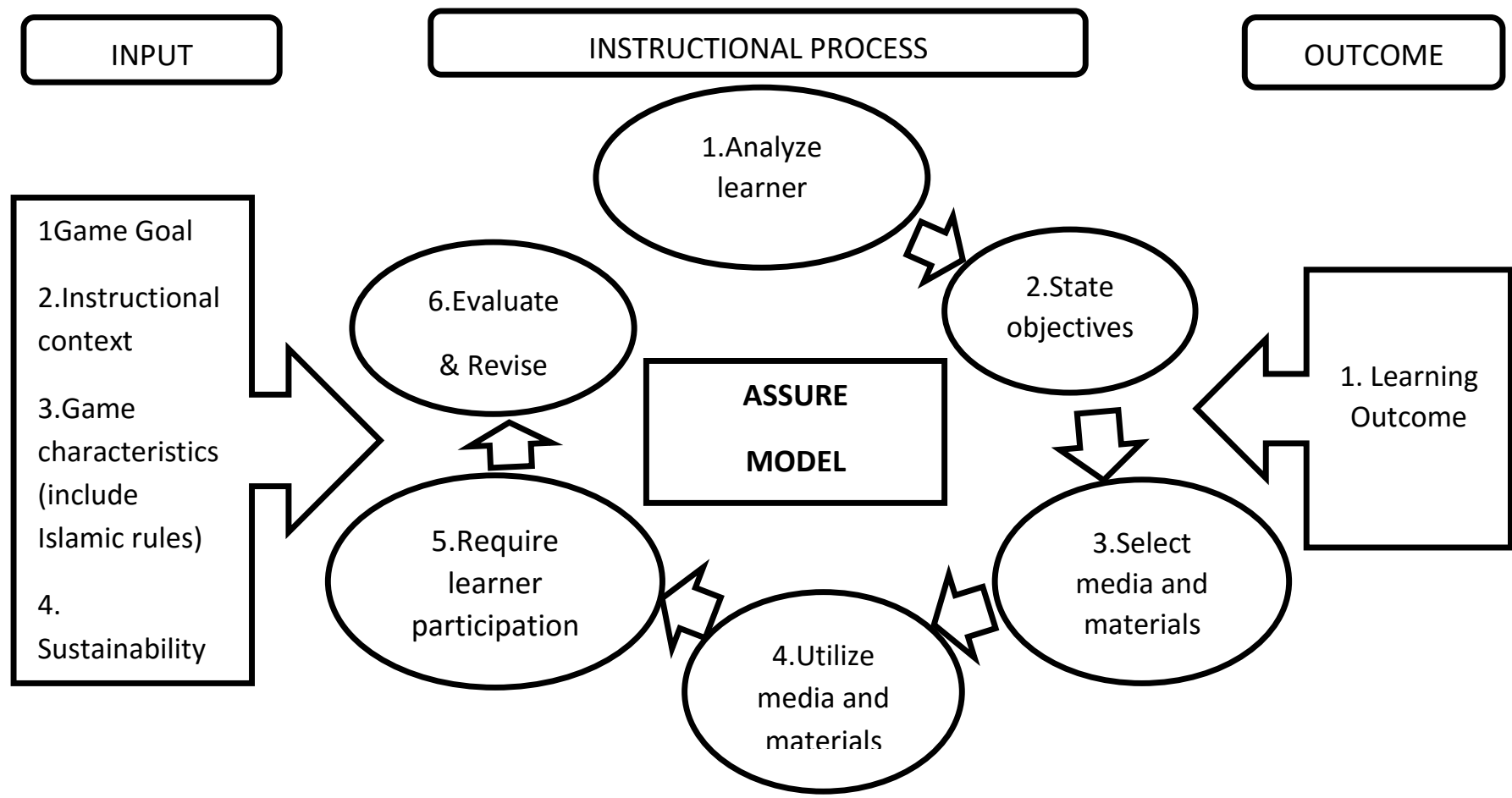

Figure 1: Adapted from Input-process-outcome game model (Garris et al, 2002) and Assure Model (Heinich, Molenda, Russell, \& Smaldino, 2013)

\section{Description of the Proposed Framework}

The game goal of the course will have a major impact on the choice of GDF. For example, if the course focuses on a complete development cycle, it should be possible to develop a game from scratch according to the specific requirements, to have tools available to specify the design and testing tools.

The ASSURE model promotes the field of education technology. It is based on the principle that no one student receives information in the same way. While the ASSURE model is used to systematically design instruction, it moves away from the traditional means of instruction (textbooks, lectures, etc.) to the use of technology for the delivery of instruction. In conclusion, the ASSURE model has six components each necessary for the successful implementation of the instruction, including: 1) Analyse learners, 2) State objectives, 3) Select methods, media and materials, 4) Use media and materials, 5) Require learner participation, and 6) Evaluate and revise.

The ASSURE model completes the assessment at the end, once the instruction has already been implemented, and seeks to learn from the difficulties that may have arisen during the lessons. Below are the detailed descriptions of the Assure Model:

Analyze Learners: General Characteristics such as Entry competencies, Learning styles, Auditory, Visual, Kinesthetic, etc. 


\section{State Objectives}

The objectives stated are statements that describe what the learner will do through instruction. In other words, the objectives are the learning results which ask what they learn from the lesson and what the learner will achieve after the lesson has been completed. The objectives you use should be as specific as possible so that the learner understands what they need to achieve. If the objectives are clearly and specifically stated, both learning and teaching will be objectively oriented.

Most objectives contain four parts:

- Audience-who are your learners?

- Behavior to be demonstrated.

- Conditions under which the behavior will be observed.

- The degree to which the learned skills are to be mastered.

\section{Select Methods, Media, \& Materials}

Once we have a clear understanding of our audience and know how the lesson should come about, it is time to select the right method for the given learning task, choose existing materials, modify existing materials or develop new materials to help us achieve this task (Smaldino, Lowther, \& Russell, 2012). The instructor should link the audience to the objectives at this step.

\section{Use Methods, Media, \& Materials}

The use of methods, media, and materials step is where you develop your media and materials implementation plan. For each type of media or material, the teacher chooses and describes how the media (or material) will be used in your lesson to help your learners meet the objectives of the lesson. The selected media, materials and technology should be focused on the implementation of the chosen method.

\section{Require Learner Participation}

The require learner participation step requires you to describe how each learner will be actively and individually involved in the lessons. Students learn best when they are actively involved in learning. Participation in learning will make this level of understanding easier. Allow them to construct knowledge rather than try to "teach" knowledge. Finally, feedback must be provided to the learner for this step before any type of assessment is carried out.

\section{Evaluate Student Performance}

The last step of the ASSURE method is to evaluate student performance. The evaluation should be matched to the objective in this respect. By assessing learners against the objectives, it can be determined whether the lessons are effective and whether any steps need to be modified or re-examined.

\section{Discussion}

The empirical research also includes studies that have examined the instructional effectiveness of games for a variety of different tasks. Empirical research does not make a compelling case for games as the preferred instructional method. In most cases, the research shows no instructional 
INTERNATIONAL JOURNAL OF ACADEMIC RESEARCH IN BUSINESS AND SOCIAL SCIENCES Vol. 10, No. 3, March, 2020, E-ISSN: 2222-6990 @ 2020 HRMARS

advantage of games over other instructional approaches (such as lectures). Games have been shown to provide effective learning in several cases but have not been compared with other instructional methods. Research does not enable us to conclude that gaming is more effective than other well-designed instructional activities.

Lessons learned; if teachers or game designers can develop a good instructional game, we can certainly produce good learners who are motivated to learn the subject on an ongoing basis. Each learner should be guided by reflecting on their own individual experiences and the meanings that these experiences have for them to make sure that the meaning of the experiences is linked to the instructional objectives.

Most of the studies begin with an "experiment of nature." Some people spend a considerable amount of time playing action video games as part of their daily routines, while others skip the genre even though they may play other types of games (Bavelier \& Green,

2009).

\section{Conclusion}

This paper reviews related studies on the potential of computer games as a teaching tool for the learning process. A suitable Game Development Framework (GDF) is chosen during the game design process, which can influence the effect of games themselves and also positively or negatively impact the learner.

The findings indicate that games can be an effective learning medium and have a more beneficial impact than traditional classroom learning if they follow all the rules, suitable an appropriate context, and specific goals in design of games. Focusing on the development of Islamic games, it is important to follow the Islamic rules and their discipline. Game contexts that are meaningful and provide well-differentiated, hierarchical goal structures are therefore likely to lead to an increase in motivation and performance for learners.

To conclude, technologies such as games are one of the instruments that can help us improve and develop our work. Thus, people who want to use these facilities should be able to use them correctly, to make the greatest possible impact and to achieve good results.

For future studies, researcher emphasize the need for more systematic meta-analysis research to explore how teachers and educators play games during the educational and learning process.

\section{Corresponding Authors}

Nadiah binti Ramlan, PhD student, Faculty of Science and Technology, Islamic Science University of Malaysia (USIM), Nilai, Malaysia, misnad_r@yahoo.com

\section{References}

Bavelier, D., \& Green, C. S. (2009). Video game based learning. Frontiers in Neuroscience, 3, 109.

Connolly, T. M., Boyle, E. A., Macarthur, E., Hainey, T., \& Boyle, J. M. (2012). A systematic literature review of empirical evidence on computer games and serious games. Computers \& Education, 59(2), 661-686.

Cruz, E. (2003). Bloom's revised taxonomy. In B. Hoffman (Ed.), Encyclopedia of Educational 
INTERNATIONAL JOURNAL OF ACADEMIC RESEARCH IN BUSINESS AND SOCIAL SCIENCES

Vol. 10, No. 3, March, 2020, E-ISSN: 2222-6990 @ 2020 HRMARS

Technology. Retrieved September 13, 2017, from

http://coe.sdsu.edu/eet/Articles/bloomrev/start.htm

Erryberry, A. (2010). "Serious games: Online games for learning." Adobe White Paper,

〈http://www.adobe.com/resources/elearning/pdfs/serious_games_wp.pdf (Sep. 10, 2012)

Dib, H., \& Adamo-Villani, N. (2013). Serious sustainability challenge game to promote teaching and learning of building sustainability. Journal of Computing in Civil Engineering, 28(5), A4014007.

Eichenbaum, A., Bavelier, D., \& Green, C. (2014). Play That Can Do Serious Good. American Journal of Play, 7(1), 50-72.

Gagne, R., Briggs, L., and Wager, W. (1992). Principles of instructional design (4th ed.). New York: Holt, Rinehart and Winston.

Gagne, R. M. (2013). Instructional technology: foundations. Routledge.

Glover, I. (2013). Play as you learn: Gamification as a technique for motivating learners. In J.

Garris, R., Ahlers, R., \& Driskell, J. E. (2002). Games, motivation, and learning: A research and practice model. Simulation \& Gaming, 33(3), 441-467

Haynes, C. C. (2008). A teacher's guide to religion in the public schools. Nashville, TN: First Amendment Center.

Heinich, Molenda, \& Russel. (2013). Model Assure. Journal of Chemical Information and Modeling, 53(9), 1689-1699.

Hannafin, M.J., \& Hooper, S.(1989). Learning the ROPES of instructional design: Guidelines for emerging interactive technologies. Educational Technology, 28(7), 14-18.

Jusoh, W. N. H. W., \& Jusoff, K. (2009). Using multimedia in teaching islamic studies. Journal of Media and Communication Studies, 1(5), 86-94

Juul, J. (2005). Half-Real: Video games between real-rules and fictional worlds. Cambridge MIT Press Books

Kapp, K. M. (2012). The gamification of learning and instruction: Game-based methods and strategies for training and education. San Francisco, California: Pfieffer.

Lederman, L. C. (1992). Debriefing: Toward a systematic assessment of theory and practice. Simulation \& Gaming, 23(2), 145-160.

Norhayati, A. M., \& Siew, P. H. (2004). Malaysian perspective: designing interactive multimedia learning environment for moral values education. Educational Technology \& Society, 7 (4), 143-152.

Parker, L. E., \& Lepper, M. R. (1992). Effects of fantasy contexts on children's learning and motivation: Making learning more fun. Journal of Personality and Social Psychology, 62(4), 625-633

Rosas, R., Nussbaum, M., Cumsille, P., Marianov, V., Correa, M., Flores, P., Salinas, M. (2003). Beyond Nintendo: design and assessment of educational video games for first and second grade students. Computers \& Education, 40(1), 71-94.

Smaldino, S. E., Lowther, D. L., \& Russell, J. D. (2012). The ASSURE Model. In Instructional Technology and Media for Learning. Retrieved from http://www.utm.edu/staff/grakes/750/750assuremodel.html

Shi, Y.-R., \& Shih, J.-L. (2015). Game Factors and Game-Based Learning Design Model. 
INTERNATIONAL JOURNAL OF ACADEMIC RESEARCH IN BUSINESS AND SOCIAL SCIENCES

Vol. 10, No. 3, March, 2020, E-ISSN: 2222-6990 @ 2020 HRMARS

International Journal of Computer Games Technology, 2015, 1-11.

Wu, B., \& Wang, A. I. (2012). A guideline for game development-based learning: A literature review. International Journal of Computer Games Technology.

Yang, Y., Wang, C., \& Lai, M. (2012). Using bibliometric analysis to explore research trend of electronic word-of-mouth from 1999 to 2011. International Journal of Innovation, Management and Technology, 3, 337-342.

Yang, Y. C., \& Chang, C. (2013). Empowering students through digital game authorship: Enhancing concentration, critical thinking, and academic achievement. Computers \& Education, 68, 334-344. 